\title{
STUDI DESKRIPTIF DETEKSI DINI PENYIMPANGAN MENTAL EMOSIONAL ( KMME, CHAT, GPPH ) PADA ANAK USIA $36-72$ BULAN
}

\author{
$\underline{\text { Sri Winarsih }}{ }^{1}$, Nuril Nikmawati ${ }^{2}$ Suprihatiningsih $^{3}$ \\ winarsihhamid@yahoo.com
}

\begin{abstract}
Background: Health efforts since child is still in the womb until the first five years of life, aimed at maintaining the continuity of life while improving the quality of life of children in order to achieve optimal growth of physical, mental, emotional and social and has a compound intelligence according to its genetic potential (Kemenkes,2013;h.1). So as a candidate of the next generation of the nation, the quality of growth of infants in Indonesia need to get serious attention that is got good nutrition, stimulation that memadaiserta affordable by quality health services including detection and early intervention deviation grow flowers (Kemenkes, 2013, h.1). Detection and growth interventions (SDIDTK) focuses on examination of KMME, CHAT, GPPH.

Objective: To describe early detection of emotional mental problems, early detection of autism, attention disorder and hyperactivity in preschoolers.

Methodology: This type of research is descriptive research. The author only describes the implementation of early detection of mental emotional deviation of children aged 36-72 months.

Results: the majority of KMME studies of 40 respondents were in an abnormal category $26(65 \%)$ and at CHAT of 40 respondents in abnormal category there were $5(12.5 \%)$, in GPPH from 40 respondents there were 2 children falling into the category abnormal.

Conclusion: The conclusion is that early detection of developmental disorder in KMME, CHAT, GPPH, the village midwife meetings with parents to conduct counseling and provide stimulation and intervention. After three months of evaluation, there is no change in referral to the hospital.
\end{abstract}

Keywords: SDIDTK Program ( KMME, CHAT, GPPH ), Preschooler

(1) : Midwifery Study Program of Magelang of Semarang Health Polytechnic

(2) : Midwifery Study Program of Magelang of Semarang Health Polytechnic

(3) : Midwifery Study Program of Magelang of Semarang Health Polytechnic

Masa lima tahun pertama kehidupan bayi merupakan masa yang sangat peka terhadap lingkungan dan masa ini berlangsung sangat pendek serta tidak dapat diulang lagi,maka masa balita disebut sebagai masa keemasan (golden period). Maka sebagai calon generasi penerus bangsa ,kwalitas tumbuh kembang balita di Indonesia perlu mendapat perhatian 
seriusyaitu mendapat gizi yang baik, stimulasi yang memadaiserta terjangkau oleh pelayanan kesehatan ber kwalitas termasuk deteksi dan inter vensi dini penyimpangan tumbuh kembang (Kemenkes,2013;h.1).

Melakukan deteksi dini penyim pangan tumbuh kembang artinya melakukan skrining atau mendeteksi secara dini adanya penyimpangan tumbuh kembang balita termasuk menindaklanjuti setiap keluhan orang tua tehadap masalah tumbuh kembang anaknya. Kegiatan stimulasi,deteksi dan intervensi dini penyimpangan tumbuh kembang balita yang menyeluruh dan terkoordinasi diselenggarakan dalam bentuk kemitraan antara keluarga (orang tua, pengasuh anak dan anggota keluarga lainnya), masyarakat (kader, tokoh masya-rakat, organisasi profesi, lembaga swadaya masyarakat dan sebagainya) dengan tenaga professional (kesehatan, pendi-dikan dan social), akan meningkatkan kualitas tunbuh kembang anak usia dini dan kesiapan memasuki jenjang pendidikan formal (Kemenkes, 2013;h.2).

Persentasi pelayanan anak balita di Jawa Tengah tahun 2015 sebesar 86,2 persen, sedikit menurun dibandingkan persentase anak balita pada tahun 2014 yaitu 86,9 persen.Berdasarkan data di wilayah Puskesmas Grabag I pada tahun 2016 jumlah TK 20 dengan jumlah murid 990, sedangkan jumlah murid untuk PAUD ada 485 dan jumlah PAUD 19 untuk murid
RA/BA ada 937 siswa dan jumlah RA/BA 19.Pelaksanaan SDIDTK dilaksanakan tiap 6 bulan sekali, yang dilaksanakan oleh bidan. Cakupan SDIDTK pada tahun 2016 yaitu $50 \%$ di semua wilayah Puskesmas Grabag I banyak kegiatan program yang harus dilaksanakan sehingga program SDIDTK yang seharusnya dilaksanakan 2 kali dalam setahun hanya terlaksana 1 kali sehingga cakupannya kurang ter-penuhi targetnya.Selain itu dalam pelaksanaan SDIDTK di wilayah Puskesmas Grabag belum sesuai dengan pedoman. Dalam pelaksanaan SDIDTK yang sudah dilaksanakan yaitu deteksi dini penyimpangan pertumbuhan (BB, TB,LK), deteksi dini penyimpangan perkembangan (KPSP, TDD, TDL) dan yang belum dilak-sanakan yaitu deteksi dini penyim-pangan mental emosional (KMME, CHAT, GPPH).

Berdasarkan studi pendahuluan tersebut peneliti tertarik untuk melakukan penelitian tentang pelaksanaan program SDIDTK terutama tentang deteksi dini penyimpangan mental emosional di Desa Kleteran wilayah Puskesmas Grabag I

\section{METODE PENELITIAN}

\section{Jenis Dan Desain Penelitian}

Jenis penelitian ini adalah penelitian deskriptif, yang menggambarkan pelaksanaan deteksi dini penyimpangan mental emosional pada anak usia 36-72 bulan dengan pendekatan / metode survey. Penelitian 
menggunakan instrument penelitian yaitu kuesioner KMME, kuesioner GPPH, Cheklist CHAT.

\section{Analisa Data}

Data hasil penelitian dianalisa dengan perhitungan prosentase yaitu menggunakan rumus :

$$
\mathrm{P}=\mathrm{F}_{\mathrm{N}}^{\mathrm{F}} \times 100 \%
$$

\section{HASIL PENELITIAN}

1. Distribusi responden berdasarkan jawaban kuesioner dari KMME

a. Normal : 14 anak ( $35 \%$ )

b. Tidak normal: 26 ( $65 \%$ )

2. Distribusi responden berdasar kuesioner CHAT
a. Resiko tinggi : 0
b. Resiko rendah : 0
c. Kemungkinan mengalami perkembangan : $5(12,5 \%)$
d. DBN : 35 ( 87,5\%)

3. Distribusi frekwensi jawaban responden berdasarkan kuesioner GPPH
a. Normal : $38(95 \%)$
b. Tidak normal : 2( $5 \%$ )

\section{PEMBAHASAN}

\section{Berdasarkan hasil kuesioner KMME}

Berdasarkan kuesioner dapat disimpulkan bahwa dari 40 responden sebagian besar berada dalam katagori 'tidak normal" yaitu sebanyak 26 anak (65\%). Interpretasi hasil pemeriksaan KMME yaitu apabila ada jawaban ya, maka kemungkinan anak mengalami masalah mental emosional. Intervensi yang dilakukan bila ada jawaban ya hanya 1 (satu), maka lakukan konseling pada ibu dan lakukan evaluasi setelah 3

1. bulan, bila anak tidak ada perubahan maka rujuk ke rumah sakit, bila jawaban ya ditemukan 2 (dua) atau lebih maka rujuk anak ke rumah sakit yang memiliki fasilitas tumbuh kembang atau kejiwaan.Rujukan harus disertai informasi mengenai jumlah dan masalah mental emosional yang ditemukan. Menurut Soetjiningsih (2014, h.325) Kesulitan /gangguan makan bukanlah diagnosis atau penyakit, tetapi merupakan gejala atau tanda adanya penyimpangan atau kelainan yang sedang terjadi pada tubuh anak. Dan pertanyaan no 9 Apakah anak anda sering kali mengeluh sakit kepala, sakit perut, atau keluhan-keluhan fisik lain nya? Pertanyaan ini ada hubungannya dengan no 8 kalau anak susah makan maka perut kosong karena perut kosong maka asam lambung meningkat dan menyebabkan sakit perut dan pusing untuk itu bidan Pembina desa memberikan konseling kepada pengasuh.

Dengan demikian anak yang tidak normal pada pemeriksaan KMME perlu dirujuk untuk mendapatkan pemeriksaan selanjutnya.

2. Berdasarkan hasil dari kuesioner CHAT

Berdasarkan dari hasil kuesioner CHAT dari 40 reponden sebanyak $5(12.5 \%)$ responden yang berada dalam kriteria kemungkinan gangguan perkembangan lain.

\section{CHAT (Cheklist for Autism in Toddler)} Dari hasil aloanamnesa didapatkan normal 35 atau $87,5 \%$ sedangkan tidak normal ada 5 atau 12,5\%. Sedangkan pada pengamatan yang ditemukan oleh peneliti 5 anak tersebut tidak bisa melakukan permintaan no 5 yaitu anak 
tidak dapat menumpuk beberapa kubus / balok menjadi suatu menara. Setelah hasil kuesioner CHAT antara pertanyaan dan pengamatan dikelompokkan 5 anak tersebut hasilnya bervariasi add. 2 anak yang hasilnya sama yaitu. A1,A4,A9,B5 dan 2 anak lagi hasilnya juga sama yaitu A5, A8,A9,B5 sedangkan 1 anak dari hasil kuesioner dan pengamatan hasilnya $\mathrm{A} 1, \mathrm{~A} 2, \mathrm{~A} 4, \mathrm{~A} 6, \mathrm{~A} 7, \mathrm{~A} 9, \mathrm{~B} 5$ dari hasil kuesioner dan pengamatan pada kelima anak tersebut jawaban 3 atau lebih menurut Kemenkes,2013 dikatagorikan "kemungkinan gangguan perkebangan lain "Dengan ditemukan nya kelainan tersebut maka penelitß. bekerja sama dengan guru dart. pengasuh untuk merujuk ke puskesmas dan apabila tidak ada kemajuan atau perkembangan maka rujuk ke Rumah Sakit yang mempunyai fasilitas klinik tumbuh kembang anak dengan dokter spesialis anak, ahli gizi, serta - atau pemeriksaan penunjang diagnostic.

\section{Berdasarkan hasil dari kuesioner GPPH \\ 5.}

Berdasarkan hasil dari kuesi6. oner GPPH dari 40 responden jawaban hasil kuesioner normal 38 (95\%) sedangkan tidak normal 2 anak (5\%). Dari hasil kuesioner jawaban responden no 26 dan 27 ditemukan hasil 14 dan 19 pada kuesioner GPPH. Menurut Kemenkes ,2013 jawaban dengan total 13 atau lebih dinyatakan "tidak normal ". Walaupun berdasarkan responden lain dijawab " selalu “ nilainya tidak lebih dari 13. intervensi yang dilakukan untuk anak yang nilainya lebih dari 13 yaitu memberikan rujukan ke Rumah Sakit yang memiliki fasilitas kesehatan jiwa atau tumbuh kembang anak untuk konsultasi lebih lanjut

\section{SIMPULAN}

\section{KMME}

Berdasarkan hasil kuesioner KMME dari 40 responden sebagian besar berada dalam katagori' tidak normal" yaitu sebanyak 26 anak (65\%). Dengan demikian anak yang tidak normal pada pemeriksaan KMME perlu dirujuk di Puskesmas untuk mendapatkan konseling dan pemerik saan selanjutnya.

\section{CHAT}

Dari hasil aloanamnesa didapatkan normal 35 atau $87,5 \%$ sedangkan tidak normal ada 5 atau $12,5 \%$. Sedangkan pada pengamatan yang ditemukan oleh peneliti 5 anak tersebut tidak bisa melakukan permintaan no 5 yaitu anak tidak dapat menumpuk beberapa kubus /balok menjadi suatu menara.

\section{GPPH}

Kesimpulan yang didapat dari hasil kuesioner GPPH normal 38 anak $(95 \%)$ sedangkan tidak normal dua anak atau $5 \%$.

\section{SARAN}

Bagi Instansi

Hasil penelitian dengan deskriptif deteksi dini penyimpangan mental emosional (KMME, CHAT, GPPH)) diatas diharapkan dijadikan dasar kebijakan oleh puskesmas setempat dalam upaya meningkatkan mutu pelayanan DDTK pada masyarakat sehingga terwujud derajat kesehatan 
anak yang optimal sebagai generasi penerus bangsa yang berkwalitas.

Bagi Masyarakat

Masyarakat diharapkan lebih memotivasi diri dalam mendapatkan pengetahuan dan pelayanan SDDTK Bagi Tenaga Kesehatan (Bidan)

Dalam pelaksanaan SDDTK diharapkan tidak berfokus pada pertumbuhan saja akan tetapi masalah perkembangan juga perlu diperhatikan

\section{DAFTAR PUSTAKA}

Arikunto, S. (2016). Prosedur Penelitian Suatu Pendekatan Praktek. Jakarta: Rineka Cipta

Aticeh, Maryamah\& Sri Sukamti. ( 2013 ). Pengetahuan Kader Meningkatkan Motivasi Dalam Melakukan Deteksi Dini Tumbuh Kembang Balita :Jurnal

Endah Purwaningsih \& Yunita Trihapsari. ( 2012 ). Hubungan Pengetahuan Bidan Tentang SDIDTK Terhadap Pelaksanaan SDIDTK Di Wilayah Kerja Puskesmas Kecamatan Karang Anom Klaten :Jurnal

Eriska Novia Saputri. ( 2014 ). PelaksanaanStimulasi Deteksi dan Intervensi Dini Tumbuh Kembang Anak Prasekolah di TK Wilayah Kerja Puskesmas Rantang Medan :Jurnal

Budiarto, Eko. (2010). Biostatistika Untuk Kedokteran dan Kesehatan Masyarakat. Jakarta: EGC
Kemenkes (2013). Pedoman Pelaksanaan Stimulasi Deteksi dan Intervensi Dini Tumbuh Kembang Anak di Tingkat Pelayanan Kesehatan Dasar. Jakarta Laporan Bulanan Puskesmas (2016)

Notoatmodjo, S. (2010).Metdologi PenelitianKesehatan. Jakarta: Rine ka Cipta

Notoatmodjo, S. (2010). Ilmu Kesehatan Masyarakat. Jakarta: Rineka Cipta Profile Jawa Tengah (2016)

Patemah, Marta Irene Kartasurya .( 2013). Faktor Determinan Pelaksanaan Stimulasi Deteksi dan Intervensi Dini Tumbuh Kembang SDIDTK Oleh Kader DI Wilayah Puskesmas di Kota Malang : Jurnal

Soetjiningsih. (2016). Tumbuh Kembang Anak. FK Universitas Udayana. Bali: EGC

Sugiyono. (2016). Statitika Untuk Penelitian. Bandung. Alfabeta

Yayasan Surya Kanti. (2016). Makalah: Deteksi Tumbuh Kembang Anak. Disampaikan pada seminar "Tumbuh Kembang Anak di Bandung, 11 Maret 2016 